\title{
植生開水路流れにおける水面変動と 流速変動との相関 CORRELATION BETWEEN WATER-SURFACE FLUCTUATIONS AND VELOCITY FLUCTUATIONS IN VEGETATED OPEN-CHANNEL FLOWS
}

\author{
襧津家久 1 ・鬼束幸樹 2 ・池谷和哉 3 \\ Iehisa NEZU, Kouki ONITSUKA and Kazuya IKETANI \\ 1正会員 工博 京都大学大学院教授 環境地球工学専攻（テ606-8501 京都市左京区吉田本町） \\ 2 正会員 博(工) 京都大学大学院助手 環境地球工学専攻 \\ 3学生員 京都大学大学院 環境地球工学専攻
}

\begin{abstract}
Turbulence characteristics of open-channel flows with the vegetated zone are greatly affected by whether the vegetation is completely soaked or not. Structures in this kind of flows become not twodimensional, but three-dimensional, when all part of the vegetation is in the water. In spite of many studies investigating these three-dimensional structures, little is examined concerning the structure near the watersurface. In this study, we simultaneously measured water-surface fluctuations and velocity in open-channel flows with the vegetated zone at the half channel width using an ultrasonic sensor measuring water-surface and a laser Doppler anemometer(LDA), and examined effects of the water-surface on three-dimensional turbulent structures. The experimental results revealed the characteristics of surface waves and correlation properties between surface waves and velocity fluctuations. Consequently, it was found how they contribute the transverse momentum mixing between the vegetated and non-vegetated zones.
\end{abstract}

Key Words : vegetated open-channel flows, three-dimensional turbulent structures, laser Doppler anemometer, water-surface fluctuation, correlation

1.はじめに

植生開水路流れに関する基礎的な研究は1992年 から1995年がピークであり、その頃にはかなり活発 に害験的および数值的研究が行われた。しかしその 後、研究は2方向に分離してしまった。つまり、一 つは直接現地の形状に近い流れ場を実験室に再現 し、その特性を明らかにしようとするものであり、 具体的には、複雑な流況を有する蛇行河道や湾曲流 などが対象とされる。もう一つは流れの物理現象の 解明に主眼をおき、元来複雑な現象を2次元に落と し、土砂輸送機構などを解明する方向である。しか し、その狭間で未だ解明されずに残された問題は多 数あり、数值計算などの分野において、実験值の データベースの供給か今も求められ続けている。以 下には、現在までに植生開水路流れがもつ特性を解 明した研究を列挙する。

池田ら ${ }^{11}$ は全断面沈水性の植生開水路流れを対象 とし、PIVにステッピングモーターを取り付けるこ とにより3次元的な可視化を実現した。そして植生 層境界面に見られる横断組織渦が流下方向に前傾 した軸をもつ楕円形であることを示した。さらに、 渦の前面部に高速下降流、渦背後に上向きの流れが 存在することを確認した。
また、禰津ら 2)は片断面沈水性の植生開水路流れ を対象に、植生領域内外の混合を研究した。彼らは LDAを用いた実験から、2次流、Reynolds応力分布お よびエネルギー収支等を示した。彼らはレイノルズ 応力分布をもとに混合の激しい場所を示した。また 彼らはPIV法を用い、水面近傍における流体の挙動 に関する研究を行った。そこで水面近傍においても 池田ら ${ }^{1)}$ の結果と同様に、渦の前端で高速流体が沈 み込み、渦の後端で低速流体が浮き上がるという瞬 間構造をとらえた。しかし、それらが水面変動とい かなる関係にあるかは言及されておらず、それに関 する研究もほとんど見当たらない。

そうした中で辻本・北村 ${ }^{3}$ は、片断面非水没の植 生開水路流れについて水面変動と流速変動とに関 する同時計測を行っている。水面変動・流速変動は 低周波で比較的規則正しく、ほぼ混合域での平均流 速程度で移流されることを指摘した。また、水面変 動は横断方向にほぼ同位相であるが、植生域と非植 生域で振幅が異なるため交番する横断水面勾配が 生じることを解明し、水面変動を媒介にして横断混 合が生じることを推測した。

しかし彼らの対象とした流れ場は非水没型なた め、現象的には比較的2次元的であり、洪水時のよ うな植生高さを越える流量に及んだ際に発生する3 
次元性の強い流れでは、水面近傍でより複雑な流れ となり、水面近傍の乱流構造に大きな変化が生じる と考えられる。

上記のようなさまざまな研究により得られた知 見が多数あり、それらの知見を総合的にとりまとめ ようとの意見が出ているにも関わらず、それは未だ に実現していない。その原因は冒頭で述べた研究の 2分化だけが原因ではない。なぜなら、この分野の 研究が始まって以来、2次流の構造、水平渦の効果 および乱れの構造は別々に論じられる傾向があっ たからである。しかも水面変動に関する研究はほと んど行われていないのが現状である。

水面が上下し得ることは、周期的な瞬間流速分布 に影響を与え、ひいては2次流の分布等に大きな影 響を及ぼすものと予測される。そしてそれら2次流 が水面渦の移流方向にその効果を伝達すると考え られる。また、水面の変位が乱流構造の変化にも大 きな影響を与え、それらが周囲に及ぼす影響も無視 することはできないと思われる。

以上のような相互作用から、水面が変動し得ると いう境界条件は、単なる弱い壁というだけではなく、 予測以上に広範囲にわたり連鎖していると推察さ れる。

そこで本研究は水面変動に着目し、それを媒介に 横断面内特性や水平面内特性を論じようとするも のである。なお、水面変動に関するデータベースが ほとんど皆無であることから、今回の実験では実河 川で見られるような弾性変形を起こす植生流れを 対象とせず、基礎的な現象の解明を目指し、剛な植 生棒を正方形配置した流れ場を対象とする。

\section{2. 実験装置及び実験方法}

本実験で使用した水路は全長 $10 \mathrm{~m} 、$ 幅 $\mathrm{B}=40 \mathrm{~cm}$ の可 変勾配型循環式直線水路であり、特に計測用区間 $3 \mathrm{~m}$ は水路側壁と底面とがそれぞれ1枚の光学ガラス製 となっている。瞬間流速の計測には水路側壁と下方 から4ビーム後方散乱型ファイバーレーザー流速計 を用いて高精度に $(u, v, w)$ の三次元計測を行った。 計測地点は、水路上流端から $5.5 \mathrm{~m}$ とした。

また、水路長 $10 \mathrm{~m}$ のち上流部 $50 \mathrm{~cm}$ 区間に遷移部 を設け、残りの区問全域にわたって、模擬植生（真 ちゅう棒をアクリル製基盤に貫入したもの）を水路 半断面に設置した。真ちゅう棒は直径 $D=2.0 \mathrm{~mm}$, 植 生高さ $H_{v}=5 \mathrm{~cm}$ である。本研究では、真ちゅう棒の配 置として1辺が $2 \mathrm{~cm}$ の正方形格子を採用した。

本実験では、図-1に示すように流下方向に $x$ 軸を、 $x$ 軸と垂直上向きに $y$ 軸を、また植生領域から非植生 領域に向かう水路横断方向に $z$ 軸をとり、原点は計 測部の植生領域側壁の植生基盤高さとした。

実験条件を表-1に示す。表中の $S_{v}$ は植生間隔で、 $\lambda H_{v}\left(\lambda=D / S_{v}{ }^{2}\right)$ は植生密度を示す無次元量である。 $S$ は路床勾配、 $H$ は低水路水深、 $Q$ は流量、 $U_{\text {max }}$ は断面 最大主流速、 $F r=U_{m} / \sqrt{g H}$ はフルード数、 $R e=4 R U_{m} / v$ はレイノルズ数、Rは径深、 $U_{m}$ は断面
表-1 水理条件

\begin{tabular}{|c|c|c|c|c|c|c|}
\hline Case & $\begin{array}{c}\text { Bed Slope } \\
S \\
\end{array}$ & $\begin{array}{c}\text { Umean } \\
(\mathrm{m} / \mathrm{s})\end{array}$ & $\begin{array}{c}\text { Discharge } \\
Q(1 / s) \\
\end{array}$ & $\underset{(\mathrm{m} / \mathrm{s})}{U \text { max }}$ & $\begin{array}{l}U_{\text {miv }} \\
(\mathrm{cm} / \mathrm{s})\end{array}$ & $\begin{array}{c}\text { Froude } \\
\text { Number } \\
\text { Fr }\end{array}$ \\
\hline FR4 & $1 / 2600$ & 0.335 & 8.93 & 0.649 & 2327 & 0.40 \\
\hline
\end{tabular}

平均流速、 $g$ は加速度、 $v$ は動粘性係数、U*は摩擦 速度を表している。実験ケース名は、FR4とする。

FLDAによる $(u, w)$ の計測の際に水路上方から 行ったのでは水面を通しての計測となるので、水面 変動の効果により高精度の計測ができない。そこで 本研究では、底面に幅 $20 \mathrm{~mm}$ 、長さ $400 \mathrm{~mm}$ 、厚さ $15 \mathrm{~mm}$ の光学ガラス製のガラス棒を植生基盤と植生基盤 の間に挿入することにより底面からの計測を行っ た。計測に用いるレンズは、レーザービームが植生 棒の間隔 $2 \mathrm{~cm}$ 通り抜けられるよう、焦点距離 400mmのレンズを用いた。

横断面内特性に関する計測点は、植生領域の横 断・鉛直境界部が密になるように不等分割し、342 点の計測を行った。これら全点に関して、水面変動 を同時に計測した。その計測位置は、流速計測と同 一断面とし、境界部近傍 $(z / B=0.51)$ と非植生領域中 央部 $(z / B=0.75)$ の 2 点とした。

本研究では上述の横断面内特性に加え、水面近傍 に関する水平面内特性に関する研究も行った。この 実験には2台のLDAと2台の波高計を使用し、これら 全てのデータを同時計測した。その際、固定点とし て境界部水面近傍に1台のLDAと1台の波高計を常 設し、移動点として固定点から流下方向横断方向と もに2cm間隔で、もう一台のLDAと波高計を動かし、 同時計測を行った。計測エリアは横断方向 $20 \mathrm{~cm}$ 、流 下方向 $16 \mathrm{~cm}$ である。

なお全ての実験を通じて、データのサンプリング 時間は約60secであり、平均サンプリング周波数は約 $200 \mathrm{~Hz}$ であった。またトラバース装置は水路に直付 けであり、 $0.01 \mathrm{~mm}$ の精度をもつ。

\section{3. 実験結果とその考察}

\section{（1）流れ場の横断面内特性に関する概況}

図-1は最大主流速 $U_{\text {max }}$ で無次元化した平均主流速 Uの等值線を示したものである。なお、図中の波線 は植生が存在する領域を表している。同一の鉛直位 置で比較すると、植生内部の等値線の值が非植生領 域の值に比べて非常に小さく、植生内部の流速が低 減されていることがわかる。また、植生内部の等値 線は比較的底面と平行であり、流れが2次元的になっ ていることがわかる。しかし、植生上部の流れでは 境界部に近づくほど等値線が勾配を有してきて、3 次元的になってきていることがわかる。非植生領域 $z / B=0.80$ 付近に注目すると、最大流速点が水面では なく植生高さ付近において見られる。これは最大流 速の降下現象と呼ばれ、滑面等流の場合はアスペク 卜比が5以下の場合に生じる2次流が原因で発生する ことがNezu \& Nakagawa)によって明らかにされてい る。今回の実験ではアスペクト比が5.6にもかかわら 
ず最大流速の降下現象が観察されたことからも、植 生の存在によって流れがより3次元的になったと考 えられる。このような片断面に植生帯を有する開水 路流における最大流速点の降下現象は非植生部分の アスペクト比や植生密度などによって決定されてい ると考えられ、今後、そのようなパラメータを系統 的に変化させた実験をする必要がある。

また、境界部の植生頂部直下における0.50の等値 線に着目すると、植生領域から非植生領域に等值線 が凸型をしていることが観察される。また比較的底 面付近に着目すると、等値線が非植生領域から植生 領域に凸型をしていることが観察される。さらに、 水面近傍では全域において非植生領域から植生領域 に等值線が歪んでいることが観察される。これらは 次に示す2次流によって説明される。

図-2(a)は2次流を $U_{\max }$ で無次元化してベクトル表 示したものであり、図-2(b)は境界部付近を拡大した ものである。まず境界部に注目すると、境界部で弱 い斜昇流的なものが存在していることが確認できる。 これは植生が弱い壁として作用しているため発生し たと考えられる。また、それを補完する流れが境界 部底面で負の横断方向流速となって現れている。そ のため非植生領域側境界部水面近傍の2次流の $w$ 成 分が打ち消され、植生領域側のそれが相対的に大き くなっていると考えられる。こうした流れが、前述 した主流速の等值線における張り出しを生じさせた 原因であると考えられる。このように、2次流はその 強度が弱いにも関わらず、主流速分布を大きく変化 させていると言える。

次に非植生領域に注目すると、図の、右上から左 下へ向かう比較的大きな流れが見られ、それは斜昇 流を補完する流れと合流しているように見える。ま た、底面付近で非植生領域壁面方向へ連続するリ ターンフローとなって一つの大きなセルを形成して いることも見て取れる。

また、水面近傍では非植生領域から植生領域に向 かう流れが全面に渡って観察できる。つまり水中を、 半植生高さ・植生高さで3つの領域に等分割すると、 それぞれに特有の流れが見られることになる。上記 のように、植生・非植生領域間の混合が特に活発で ある領域は、下から2つの領域であるが、水平渦が通 過する水面近傍での流れの挙動は、横断面内の解析 からでは明確につかむことが困難である。時間的な 変化や流下方向に及ぼす影響等、より詳細な解析が 必要であると思われる。そこで本研究では、（3） 節において水面近傍に関する水平面内特性を検討す る。

次に、2次流の発生機構を調べるために、渦度方程 式を用いる。同式において、左辺は移流項(A)、右辺 第1項は発生項(B)、第2項はReynolds応力項(C)、第3 項は粘性項(D)である。これらの諸量は2階の微分処 理を必要とされるため、通常精度よく計算すること は困難とされるが、今回平滑化スプライン補間を施 すことで精度の高い定量的評価に成功した。

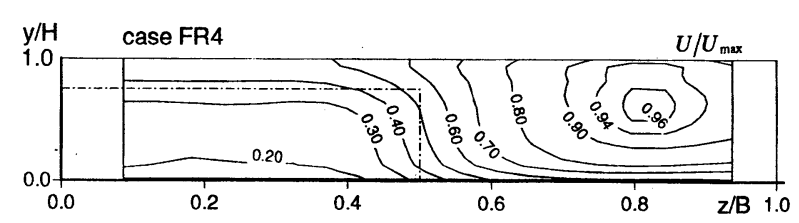

図-1 平均主流速

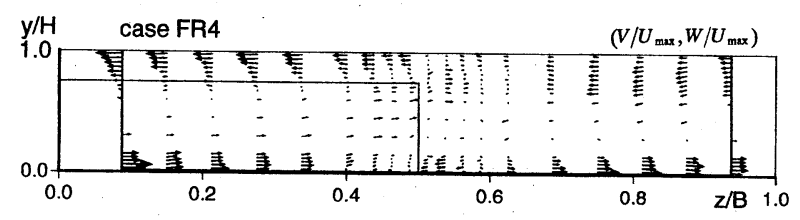

図-2(a) 2 次流ベクトル図

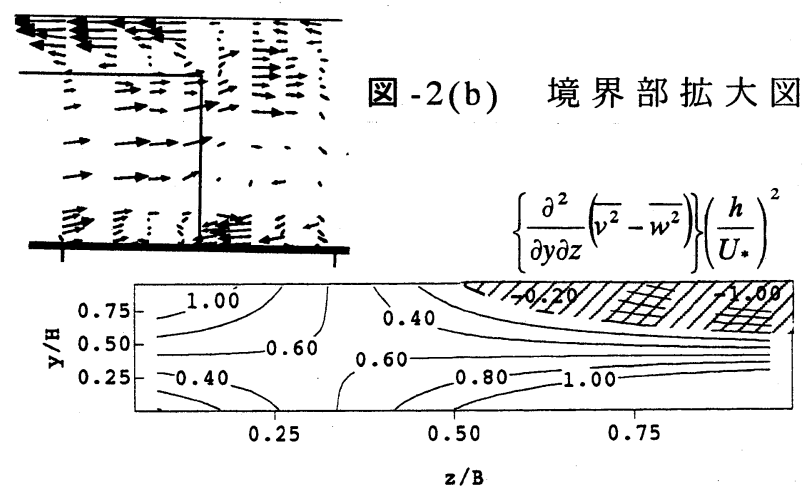

図-3 発生項 (B)

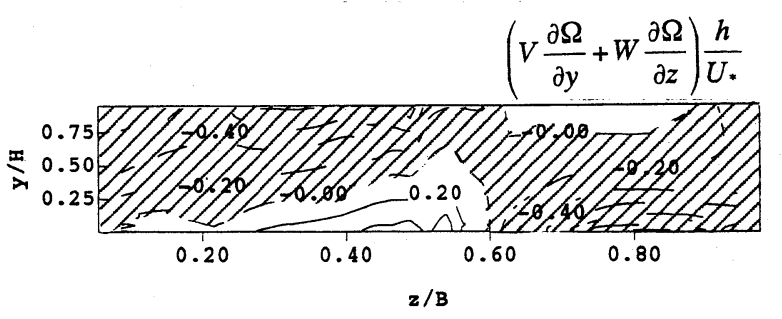

図 -4 移流項 (A)

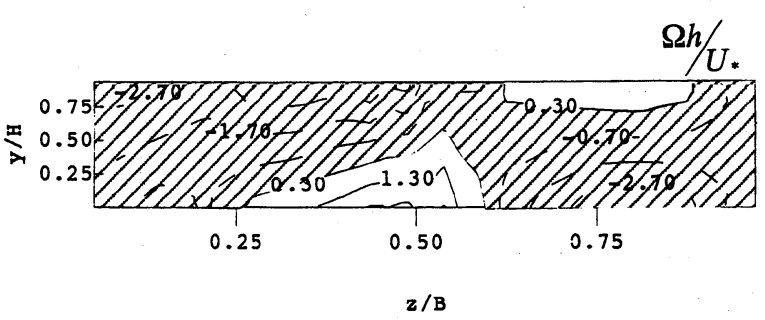

図 -5 渦度

$$
\begin{aligned}
& \underbrace{V \frac{\partial \Omega}{\partial y}+W \frac{\partial \Omega}{\partial z}}_{\text {(A) }}=\underbrace{\frac{\partial^{2}}{\partial y \partial z}\left(\overline{v^{2}}-\overline{w^{2}}\right)}_{\text {(B) }}+\underbrace{\left(\frac{\partial^{2}}{\partial z^{2}}-\frac{\partial^{2}}{\partial y^{2}}\right)}_{\text {(C) }})+\underbrace{\nu \nu^{2} \Omega}_{(\mathrm{D})} \\
& \text { in which } \Omega \equiv \frac{\partial W}{\partial y}-\frac{\partial V}{\partial z}
\end{aligned}
$$

図-3は式(1)中の発生項(B)であり、渦度の発生項を 意味する。したがって、この值の大きなところで渦 度の発生が強くなると考えられる。図より、水路の 四隅で絶対值の大きな值が見られる。これらは、2 次流べクトル図で現れていた水面近傍および底面付 近での大きな流れと対応していると思われる。 
図-4は移流項(A)である。式中の項の関係について、 一般には(B)項と(C)項が釣り合い、粘性項(D)がほぼ ゼロであることから、(A)項は小さな值をとると言わ れている。今回の実験においても全域にわたって、 (B)項に比べて小さな值が見られる。よって植生開水 路流れにおいても、(B)項と(C)項は釣り合っている ことが示唆された。

図-5に渦度 $\Omega$ の等値線図を示す。符号は右回りを 正とした。水路全体において負の值をとっている。 これは水路全体を反時計回りに回る2次流と対応し ている。また、水路の四隅において渦度の強度が極 小を示しているが、これは、図-3で示されたように この領域で渦度の発生項が極值を持つことと対応し ている。

図-6は鉛直方向Reynolds応力 - $\overline{u v}$ である。植生開 水路流れでは、主流速の鉛直分布が植生領域内では 流速分布が指数型となる。しかし非植生領域におい ては対数則分布となるため、今回は対数則より求め た摩擦速度の、非植生領域側の平均値を用いて無次 元化を行った。

鉛直方向Reynolds応力- $-\bar{v}$ は、境界部からやや植 生領域に入ったところで鉛直方向に大きな勾配を持 つ分布形状になっている。また、植生頂部よりやゃ 上方で極大值を取ることが認められる。これらは、 池田ら ${ }^{1)}$ が可視化実験で確認した植生頂部での横断 渦に対応していると考えられる。

横断方向Reynolds応力 $-\overline{u w}$ は植生領域と非植生 領域との間の運動量輸送を考える上で重要であり、 したがって植生を有する河道設計において重要な水 理量である。

図-7は横断方向Reynolds応力ーこれも対数則より求めた摩擦速度の、非植生領域側 の平均値を用いて無次元化した。

極大值を取る位置は、図-2(b)を参照すると斜昇流 に起因する2次流セルの位置に対応していることが わかる。またここでは、図-1で観察されるように、 主流速の横断方向の勾配 $\partial U / \partial z$ が大きい領域と対応 している。つまり植生の存在によって植生内部では 流速が遅められ、そのために発生する横断方向のシ ア一のためにReynolds応力 - $\overline{u w}$ は増加しているも のと考えられる。

\section{（2）水面変動と流速変動の相関（横断面内特性）}

境界部 $(z / B=0.50)$ に設置した波高計によって流 速と同時計測した波高のデータから、各流速成分の 変動と水樑の変動との相関係数を算出した。図-8に 相関係数の等値線 $C_{u h} 、 C_{v h} 、 C_{w h}$ を示す。各流速 変動成分のRMSの平均值と水面変動のRMSの平均 值を用いて無次元化した。

まず主流速と水深の相関係数 $C_{u h}$ について、正の 相関が植生領域側に、負の相関が植生領域側（境界 部を除く)に大きく広がっている。

0.0 の等値線に着目すると、植生高さ付近で非植生 領域に張り出しているのが観察される。そして底面

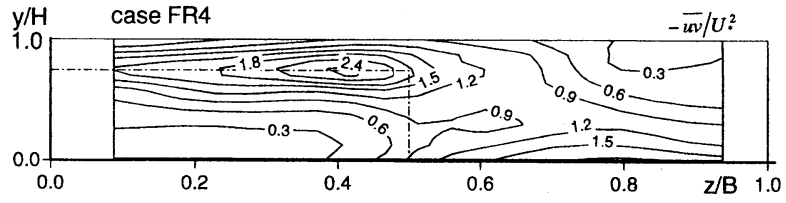

図-6 鉛直方向レイノルズ応力 $-\overline{u v}$

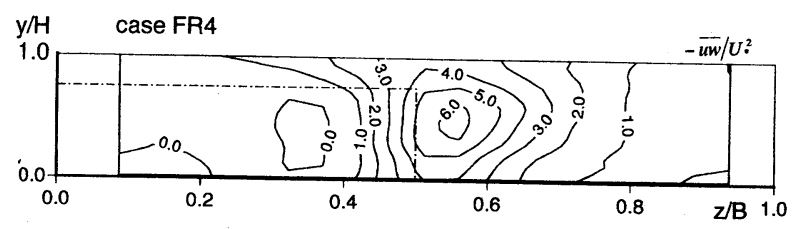

図-7 横断方向レイノルズ応力 $-\overline{u w}$
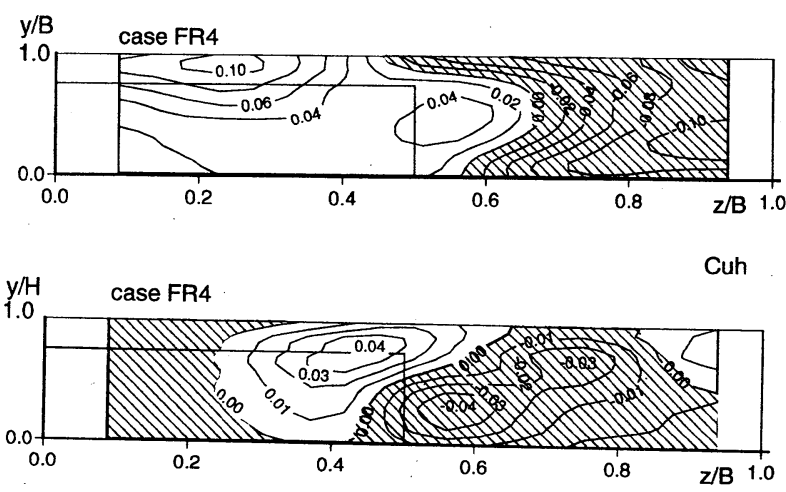

Cvh

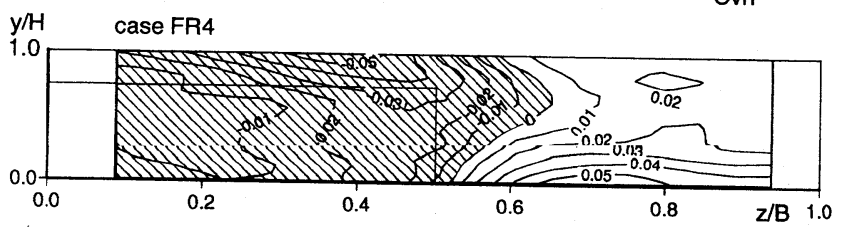

Cwh

図 -8 水面変動と流速変動の相関

$$
\text { (上： } C_{u h} \text { 、中 : } C_{v h} 、 \text { 下 }: C_{w h} \text { ) }
$$

付近で植生領域側へ張り出している。つまり境界部 やや非植生領域側で鉛直方向に位相差があることに なる。これは渦の通過時、つまり水深が低くなって いる際は、水面近傍と底面付近で高速流体が、鉛直 方向に中間の領域で低速流体が存在していることを 指している。本実験のような水没型植生流れは、辻 本・北村 ${ }^{3)}$ が対象とした非水没型植生流れと比べて3 次元性の強い流れになっていることが確認される。

次に鉛直方向流速成分と水深の相関係数 $C_{v h}$ につ いて、境界部において鉛直方向に符号の変化を伴う 大きな変化が見られる。半植生高さを境に、それよ り上方では正の相関が、それより下方では負の相関 が見られる。これは、池田ら ${ }^{1)}$ の指摘した植生層上の 横断渦に起因していると思われる。つまり、渦の存 在によって水深が上昇した瞬間に境界部の水面付近 の流体は上昇するが、その流体を補償するために非 植生領域の流体塊が境界部の半水深以下の領域にも 

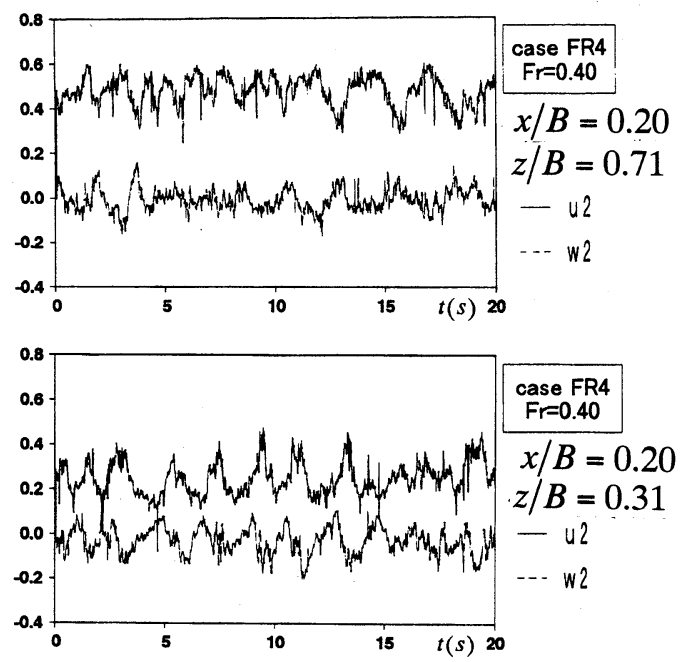

図-9 流速変動 $\left(u_{2}, w_{2}\right)$ の 時系列

（上：非植生領域、下：植生領域）

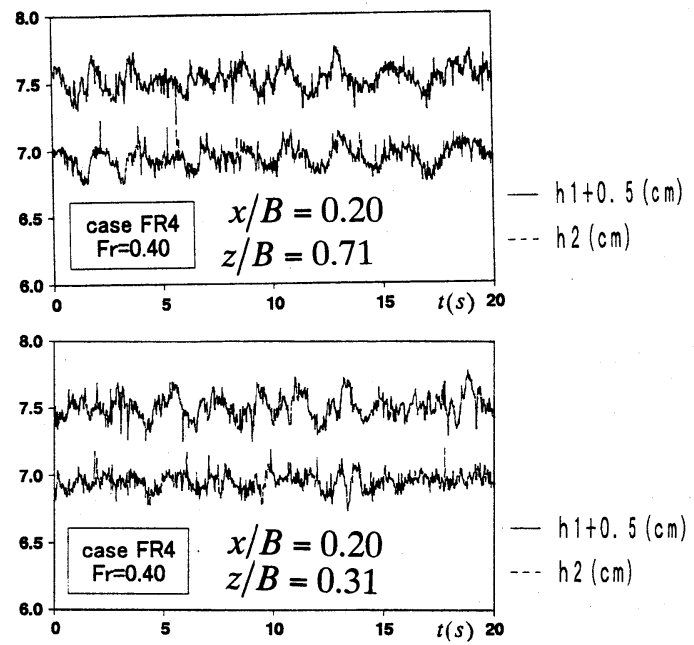

図-10 水面変動 $\left(h_{1}, h_{2}\right)$ の 時系列

(上：非植生領域、下：植生領域）
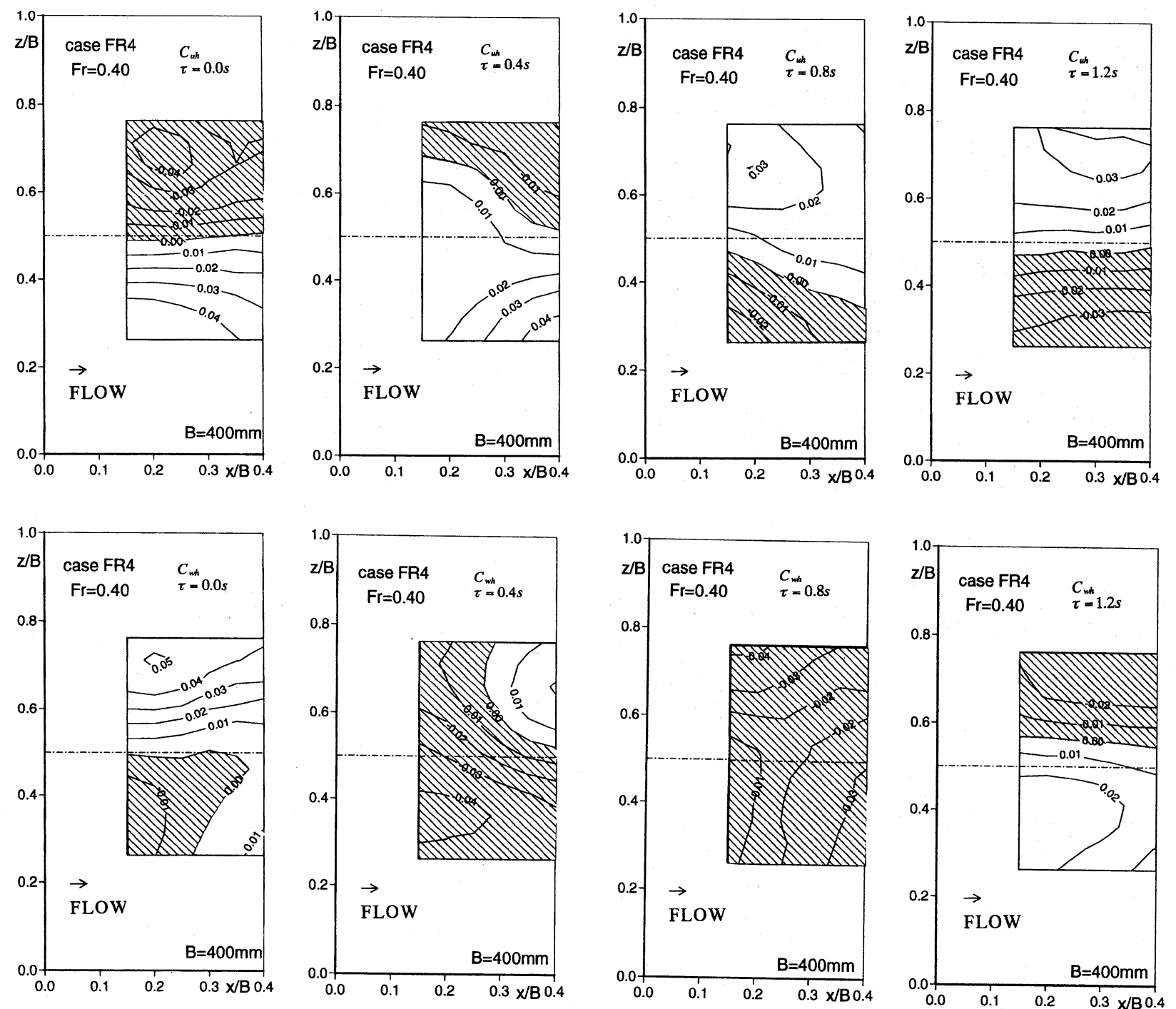

図-11 水面変動と流速変動の相関

( 上(a) : $C_{u h}$ 、下 (b) $\left.: C_{w h}\right)$ 
ぐり込んでいると考えられる。

横断方向流速成分と水深の相関 $C_{w h}$ について、 0.0 の張り出しに関して $C_{u h}$ と同様の結果が見られる。 ただし逆の符号になっている。これは、主流速と横 断方向流速の変動の挙動が類似しており、なおかつ その変動の符号が逆であることを意味している。つ まり、境界部やや非植生領域側では、渦が通過し水 深が浅くなる瞬間に水面近傍と底面近傍に非植生領 域から植生領域に入り込む高速流体が存在し、中間 領域では逆に植生領域から非植生領域に入り込む低 速流体が存在することを表している。

水面近傍に関して3枚の図面を比較すると、ピーク を取る位置が主流速との相関は植生領域の中央付近 であるのに対して、鉛直方向流速や横断方向流速に 関してはそれよりやや境界部よりであることが認め られる。しかしここでも水面近傍の相関構造に関し て概括的な結果しか得られないため、次節で移流過 程なども含めて検討する。

\section{（３）水面変動と流速変動の相関（水平面内特性）}

上流境界部 $(z / B=0.51)$ に波高計 $\left(h_{1}\right)$ とレーザー流 速計 $\left(u_{1}, v_{1}\right)$ を常設し、下流部で横断方向と流下方向 に $2 \mathrm{~cm}$ 間隔で波高計 $\left(h_{2}\right)$ とレーザー流速計 $\left(u_{2}, w_{2}\right)$ を 移動させて、同時計測を行った $(y / H=0.93)$ 。それ らのデータから、各流速成分の変動と水深の変動と の相関係数を算出した。

まず、図-9に各領域における瞬間流速変動 $u$ および $w$ の時系列変化を示す。 $u$ と $w$ の位相差をみると、植 生領域内でおよそ半波長ずれている。

次に、図-10に各領域における瞬間水面変動 $h_{1}$ およ びh $h_{2}$ の時系列変化を示す。どの断面も境界部の変動 とほぼ同位相であることが確認できる。植生領域の 変動は非植生領域の変動に比べて相関が弱く振幅も 小さく、境界部の振幅が最も強いこともわかる。つ まり境界部を中心として植生領域および非植生領域 にまたがる大きな渦が移流していると言える。

図-11(a)、図-11(b)に相関係数の等值線を示す。(a) は主流速変動と水面変動の相関を、(b)は横断方向流 速変動と水面変動の相関を示している。これらは遅 れ時間 $\tau=0.0 \mathrm{~s} 、 0.4 \mathrm{~s} 、 0.8 \mathrm{~s} 、 1.2 \mathrm{~s}$ の図を並べて示した。 以下(a)の相関を $C_{u h}$ 、(b)の相関を $C_{w h}$ と略記する。

まず $C_{u h} \cdot C_{w h}$ ともに植生側と非植生側の符号が 逆転していることが観察される。これは水平渦が回 転しながら硫化するために生じているものである。 $C_{u h}(\tau=0.0 s)$ について、非植生領域で負の值が、植 生領域で正の值が広く分布していることがわかる。 さらに、 $C_{w h}(\tau=0.0 s)$ は、 $C_{u h}(\tau=0.0 s)$ の分布と正 負が入れ替わった分布を示していることもわかる。 このことから、水深が下がるときに（つまり水平渦 が通過するときに）、非植生領域から高速流体が沈 み込み、植生領域から低速流体が沸き上がることを 示している。逆に水深が上がるときには、境界部か ら非植生領域および植生領域に沸き上がりが起こっ
ていることが類推できる。

また、遅れ時間を追うごとに移流過程が観察され る。これより、渦の周期は約 $2.0 \mathrm{~s} \sim 2.4 \mathrm{~s}$ と推測される。 ここで $C_{u h} \cdot C_{w h}$ ともに、今回の計測範囲ではほぼ 分布形状を変えず、同じ強度で移流しているのが見 て取れる。これは、水平渦は回転に際して、uがwに wがuに入れ替わるだけで、その構造を変えないこと を意味している。つまり水平渦は凍結乱流的に流れ 場の流速に乗って流れていると考えられる。

\section{4.おわりに}

本研究では、水面変動と瞬間流速の同時計測によ り、水面変動と組織乱流構造の関係を実験的に検討 したものである。得られた知見を簡単に示す。まず、 沈水性の植生開水路流れでは、水面変動に関して、 水面は境界部を中心とし、同位相で山・谷の変動を 繰り返し、結果として2つの交番を生じていることが わかった。

流速変動に関しては、水面近傍の流れと植生棒高 さ以下の流れでは大きな違いがあり、大きく3つの領 域に分類できることがわかった。つまり、高速流体・ 低速流体とが混在する水面近傍、非植生領域から植 生領域への流れが卓越する底面近傍、それとは逆の 流れが卓越する中間領域である。そして一連の組織 構造として高速流体、低速流体の作用により渦が発 生し、その渦と渦の間に境界部を中心とする沸き上 がりが起こっていることを指摘した。

今後は、さらにフルード数を増加させた場合の データの集積を行い、比較検討をする予定である。 また、PIV(Particle-Image-Velocimetry)等を用いた可視 化によって画像解析を行い、植生開水路流れにおけ る流速変動と水面変動に関する相関構造の全貌を解 明していきたい。

\section{参考文献}

1）池田駿介・金沢稔 -太田賢一: 可堯性を有する沈 水性植生層上の組織渦の三次元構造と穂波の発 生, 土木学会論文集, No. 515 II-31, pp. 33-43, 1995.

2) 襧津家久・鬼束幸樹・定免英樹 : 植生を有する開 水路流の横断面内乱流特性，ながれ, Vol. 117, pp. 357-367, 1998.

3) 辻本哲郎・北村忠紀 : 側岸部に植生群落を有する 開水路流れの横断混合機構に関する実験的研究， 土木学会論文集, No. 491 II-27, pp. 67-70,1994.5

4) Nezu, I \& Nakagawa, H: Turbulence in OpenChannel Flows, IAHR-Monograph, Balkema, Rotterdam, 1993.

5) Nezu, I \& Nakagawa, H: Cellular secondary currents in straight conduit, Journal of Hydraulic Engineering, Vol. 110, No. 2, 1984.

(1999.9.30受付) 